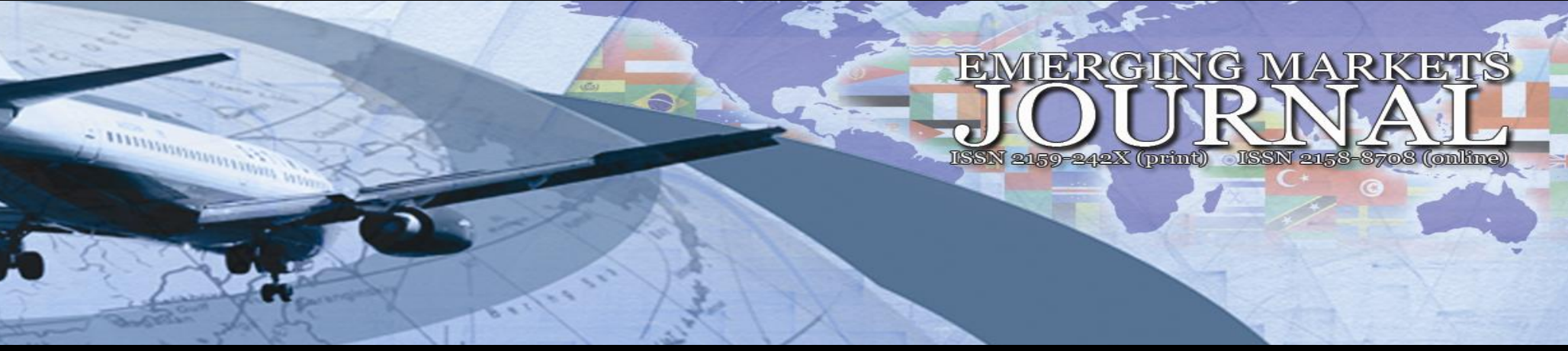

\title{
Consumption Characteristics Mapping of the Base of the Pyramid (BOP) Population in Brazil
}

\section{Renata Giovinazzo Spers}

Universidade de São Paulo Faculdade de Economia, Administração e Contabilidade Departamento de Administração, Brazil | e-mail: renatag@usp.br / renatag@fia.com.br

\section{James Terence Coulter Wright}

Universidade de São Paulo Faculdade de Economia, Administração e Contabilidade Departamento de Administração, Brazil | e-mail: jtwright@usp.br

\section{Volume 5 No 2 (2015) ｜ＩSSN 2158-8708 (online) ｜ＤOI 10.5195/emaj.2015.74 | http://emaj.pitt.edu |}

\section{Abstract}

The objective of this study is to outline a diagnosis of the Base of the Pyramid Population (BoP) in Brazil, regarding their size and consumption characteristics. This is a relevant and current issue, considering that BoP needs to be understood as a large potential market with its own logic, also representing a large productive potential, which, if well developed, will bring very positive impacts to these communities. To achieve this, a theoretical survey was run. After that, research was made based on secondary data about Brazilian BoP population participation and a mapping of their consumption profile, identifying main categories of goods consumed. This research generated meaningful results for society, companies and the academy, hopefully consolidating a relevant line of research and management education.

Keywords: Base of the Pyramid Population, Brazilian Market, Low Income Markets, Market Needs, Products and Services $(\mathrm{cc}) \mathrm{BY}$

New articles in this journal are licensed under a Creative Commons Attribution 3.0 United States License.

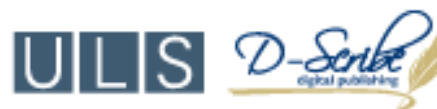

This journal is published by the University Library System of the University of Pittsburgh as part of its $\underline{\mathrm{D} \text {-Scribe Digital Publishing Program, and is cosponsored by the University of Pittsburgh Press. }}$ 


\section{Consumption Characteristics Mapping of the Base of the Pyramid (BOP) Population in Brazil}

\section{Renata Giovinazzo Spers \\ James Terence Coulter Wright}

1. Introduction: context, research problem and objectives

The literature on the base of the pyramid (BoP), developed in Brazil and abroad mostly from the late 1990s has highlighted the benefits of the establishment of mutual value and opportunities for businesses and communities, according to studies conducted by Prahalad and Hammond, 2002; Prahalad and Hart, 2002; Giovinazzo, 2003; Prahalad, 2004 and Spers, 2007.

There has been a growth in the profitable businesses, which are able to successfully meet the BoP market needs and at the same time, get a reduction in poverty and a higher inclusion of this portion of the population into the economy and society, according to studies carried out by London et al (2007) and London, Anupindi and Sheth (2009).

From the companies viewpoint, an effort is observed aiming at the new products and services and new processes development, as well as adjustments to the business strategies towards the suitability to the base of the pyramid markets, according to studies conducted abroad by Prahalad (2004) Prahalad (2005), Hart (2005), Hart and London (2005), Hammond et al (2004), Hammond et al (2007) and London (2004).

Also in Brazil, studies and researches can be identified that show the companies strategies to meet the base of the pyramid market needs, such as those by Giovinazzo (2003), Spers and Wright (2006) and Spers (2007), which demonstrate that companies focusing on BoP have obtained better results, in terms of growth, profits and operational results, than those companies focusing on social classes A and B.

However, in this context it also becomes relevant to know the base of the pyramid needs, as consumers and also as producers. Given the above, a question arises: What are the consumption characteristics of the $\mathrm{BoP}$ population in Brazil?
It is understood that this is a relevant and current issue, bearing in mind that BoP needs to be understood as a large potential market with its own logic, besides also representing a large productive potential, which, if well developed, will bring very positive impacts to these communities. This research is expected to generate meaningful results for society, companies and the academy, with the potential to be developed over the medium and long term, with a view to consolidating a relevant line of research and management education.

Taking into consideration the research questions submitted, the main objective of the study is to map out a diagnosis of the BoP population in Brazil, with regard to the consumption dimension.

The specific objectives of the study are:

1. To identify the current participation of the BoP population in Brazil;

2. To map out the consumption profile of the BoP population in Brazil, identifying the main categories of products and services consumed;

3. To analyze if the characteristics of $\mathrm{BoP}$ consumption in Brazil are consistent with the national and international literature on the theme.

2. Characterization and behavior shopping of the BoP in Brazil

The social stratification may be defined according to different parameters. In his work, Prado (2008) carried out an effort to seek in the Brazilian academic literature the classification of popular market and realized that there is no consensus regarding this classification, it can be related to Brazil Criterion; to the amount of minimum wages and to the very understanding of each author about the formation of the low-income market in Brazil, according to data in Table 1 below. 
Table 1 - Low income in Brazilian academic papers

\begin{tabular}{|c|c|}
\hline Authors & Classification \\
\hline Schneider (1978) & $\begin{array}{l}\text { Monthly household income up to } 5 \\
\text { minimum wages }\end{array}$ \\
\hline $\begin{array}{l}\text { Arruda (1981); } \\
\text { Zamith (1993); } \\
\text { Alves (2006); Reis } \\
\text { (2006) }\end{array}$ & $\begin{array}{l}\text { Monthly household income less than } \\
\text { or equal to } 3 \text { minimum wages }\end{array}$ \\
\hline $\begin{array}{l}\text { Giovinazzo (2003); } \\
\text { Issa Jr. (2004); Barki } \\
\text { (2005); Spers and } \\
\text { Wright (2006) }\end{array}$ & $\begin{array}{c}\text { Socioeconomic class C (monthly } \\
\text { household income between } 4 \text { and } 10 \\
\text { minimum wages) and } \\
\text { Socioeconomic classes D and } \mathrm{E} \\
\text { (monthly household income less than } \\
4 \text { minimum wages) }\end{array}$ \\
\hline $\begin{array}{l}\text { Marques (2004); } \\
\text { Lima, Gosling and } \\
\text { Matos (2008) }\end{array}$ & Socioeconomic classes C and D \\
\hline $\begin{array}{l}\text { Mattoso and Rocha } \\
\text { (2005); Mattoso } \\
\text { (2005); Castilhos } \\
\text { (2007) }\end{array}$ & Housing location \\
\hline $\begin{array}{l}\text { Parente, Barki and } \\
\text { Kato (2005) }\end{array}$ & $\begin{array}{c}\text { Household income less than } \mathrm{R} \$ \\
1.200,00 \text {. This amount represented at } \\
\text { the time the study was conducted, } 4 \\
\text { minimum wages }\end{array}$ \\
\hline $\begin{array}{l}\text { Moura et al. (2006); } \\
\text { Ponchio, Aranha and } \\
\text { Todd (2006); } \\
\text { Ponchio and Aranha } \\
\text { (2007) }\end{array}$ & $\begin{array}{l}\text { Monthly household income below } 4 \\
\text { minimum wages }\end{array}$ \\
\hline $\begin{array}{l}\text { Assad and Arruda } \\
\qquad \text { (2006) }\end{array}$ & $\begin{array}{c}\text { Socioeconomic classes } \mathrm{D} \text { and } \mathrm{E} \text {, } \\
\text { with monthly household income less } \\
\text { than } 4 \text { minimum wages }\end{array}$ \\
\hline $\begin{array}{l}\text { Barros (2006a); } \\
\text { Barros and Rocha } \\
\quad(2007)\end{array}$ & $\begin{array}{c}\text { Group of domestic workers residents } \\
\text { in the Baixada Fluminense } \\
\text { neighborhoods, State of Rio de } \\
\text { Janeiro }\end{array}$ \\
\hline Barros (2006b) & $\begin{array}{l}\text { Definition through the logic of } \\
\text { "lacking" because they do not have } \\
\text { the required goods to be fully } \\
\text { included in the consumer society, } \\
\text { ended up being disqualified as } \\
\text { consumers }\end{array}$ \\
\hline $\begin{array}{c}\text { Chen (2006); } \\
\text { Moreira (2006); } \\
\text { Veloso e Hildebrand } \\
\text { )(2006); Veloso, } \\
\text { Hildebrand and Daré } \\
\text { (2008) }\end{array}$ & Socioeconomic classes C, D and E \\
\hline $\begin{array}{l}\text { Sobral et al. (2006); } \\
\text { Parente, Barki and } \\
\text { Kato (2007) }\end{array}$ & $\begin{array}{l}\text { Monthly household income below } 10 \\
\text { minimum wages }\end{array}$ \\
\hline $\begin{array}{l}\text { Silva and Parente } \\
\text { (2007) }\end{array}$ & $\begin{array}{l}\text { Monthly household income between } \\
2 \text { and } 5 \text { minimum wages }\end{array}$ \\
\hline $\begin{array}{l}\text { Monteiro, Silva and } \\
\text { Ladeira (2008) }\end{array}$ & $\begin{array}{l}\text { Monthly household income below } \\
\text { R } \$ 1.000,00\end{array}$ \\
\hline
\end{tabular}

Source: Prado (2008)
A common and trustworthy definition is the one that uses the classification by average household monthly income, based on data from the National Household Sample Survey (PNAD-IBGE, 2010). Based on this study, the popular class (or the base of the pyramid, as defined in this study) is made up of families earning average income up to 10 minimum monthly wages.

For IBGE (2010), the class A is made up of the families that receive above twenty minimum monthly wages, the class B consists of the families that receive between ten and twenty minimum monthly wages and the popular classes $\mathrm{C}, \mathrm{D}$ and $\mathrm{E}$, consists of the families that receive below ten minimum monthly wages, being divided into the following categories: a) between five and ten minimum monthly wages the representatives of the class $\mathrm{C}$, b) between two and five minimum monthly wages the representatives of the class $\mathrm{D}$ and $\mathrm{c}$ ) the families that receive less than two minimum monthly wages the representatives of the class $\mathrm{E}$.

This study will adopt the classification criteria proposed by the IBGE (2010), being the criterion of average household monthly income a metric available and reliable, which qualifies it as an option to be used for this study.

Spers and Wright (2011) highlights that the base of the pyramid population consists of the classes $\mathrm{C}, \mathrm{D}$ and $\mathrm{E}$, a group of potential customers who, if included as part of the consumer market, can generate lots of wealth and, consequently, social inclusion and social welfare state.

\section{a. The shopping behavior of the base of the pyramid (BoP) population}

The change in the Brazilian socioeconomic structure was due to a better income distribution and the increase in average household income. In accordance with analysis carried out by Wright and Cardoso (Spers cited in Wright, 2006) it was observed an increase in the number of families with average monthly income between 2 and 5 minimum wages in the period 1992-2004. The higher income led to the change of members from the class $\mathrm{D}$ and $\mathrm{E}$ to the class $\mathrm{C}$ over the years. The classes $\mathrm{C}, \mathrm{D}$ and $\mathrm{E}$, together, accounted for $88 \%$ of the total population in 2011 (CPS / FGV, 2012).

In this scenario, where most of the population belongs to the base of the pyramid, attention should be given to the consumption of popular and essential goods to meet the demands of low-income market. Cobra (2009) states that the popular class purchases, primarily for survival, while the upper class purchases also to boast the luxury. 
Vaz (2006) points out that the consumers with low purchasing power are seen, generally, as people who do not have money to spend and therefore appreciate lower prices, second-tier brands and are dependent on credit plans systems. However, considering this market size, the lower classes represent a significant purchasing power that is waiting to be explored. The base of the pyramid represents a large share of Brazilian society that, despite having a restricted budget, is increasingly exposed to the advertising, publicity and influences that awaken the consumption desire and has available income to choose what to purchase, being the price, although important, only one of the attributes to be analyzed in the purchasing process.

Complementing this analysis, Wright et al (2000) apud (as cited) in Spers and Wright (2011) emphasize that, although relevant, price is not the only determinant factor in the purchasing process of popular class: The stores and products must be attractive, be stylish and these income range customers must be treated with respect and, in addition, these popular consumers' desires and needs must be satisfied, which is not always reflected by what is cheaper and required for survival.

According to Prahalad (2005), the consumption capacity creation is based on three basic principles: Purchasing power, access and availability of goods/services. The author also states that the BoP population is highly brand aware. And it is also extremely conscious about value, considering the necessity and the impossibility of repurchasing.

According to a study disclosed by BCG (2002), carried out with consumers of popular class (restricted to people in the age group of 18-64 years old and heads of household) in Brazil, the base of the pyramid consumer is subdivided into three groups according to their consumption profile: The consumerist, the planner and the reserved. The "consumerist" consumer profile is described as an adventurous, outgoing, vain and dreamlike person. This base of the pyramid group grew accustomed to living with debt and do not worry too much about it. It is a consumer who buys for pleasure, the products related to personal image being the focus of its consumption. This portion represents $40 \%$ of the studied public, featuring a large consumer market in the sector of fashion and beauty, for example, beyond the staple products.

The "planner" consumer profile, according to BCG, 2002, is more cautious. This consumer spends his income sparingly and is skeptical regarding to advertising. Because he cares about the future, he invests in his education and in their children. He hates debts and, in few months, manages to save a buck. This profile, although at first glance, has few consumption off their essential needs, knows very well the products he purchases as well as his consumption desires. Thus, this is a challenging consumer profile who gives great importance to the low price, but also resorts to a higher amount when he realizes that the quality of the product or service is relevant to this expenditure. This consumer represents $36 \%$ of the studied base of the pyramid total consumers.

Finally, the research shows that the minority of study population (24\%) consists of retracted consumers: People who focus on price and buy only if it is necessary: Their needs and their families' needs, the paper states. This profile resembles the ideal of Cobra (2009) and of common sense when it comes to the consumer of the base of the pyramid. The conclusion of the paper is that, despite being difficult to speak of a standard for the popular class, a feature common to all profiles comes to the fore: Consumers pertaining to the popular class neither invest nor save, they consume.

According to the Data Popular (2006), young people prevails in the popular classes, $30 \%$ of the class $\mathrm{C}$ is comprised by people under 20 and in classes $\mathrm{D}$ and $\mathrm{E}$, the percentage is $41 \%$. This ratio significantly impacts the consumption profile, and stands out opportunities in some product segments, among them the education of these young people.

According to research by BCG (2002), the price has a weight of $31 \%$ to $38 \%$ on the purchase decision, according to the product category. But despite the price being relevant, this group has increasingly trying to project its quest for social status in products that class $\mathrm{A} / \mathrm{B}$ consumes as well as looking for quality in the purchased goods and services.

The low-income consumers have the need for social inclusion, as opposed to the upper classes consumers, who want to be unique. Poorer consumers feel excluded from society; living in the fringes of society they feel inferior. The consumption, in turn, offers a sense of belonging in the group, is a way to feel as a part of society. To consume is good for self-esteem of such consumers (Oliveira, 2006).

Based on these concepts, secondary data will be analyzed, considering the following framework:

1. The current participation of the BoP population in Brazil will be analyzed, considering that BoP population is made up of families earning average income up to 10 minimum monthly wages.

2. The consumption profile of the BoP population in Brazil will be mapped out, identifying the main categories of products and services consumed, in the light of the literature review. 


\section{Methodological approach}

Green and Carmone (1988) and Malhorta (1996) point out that once the research problem has been clearly formulated, it is needed to develop the research planning, organizing the conditions for data collection and analysis. Considering this study, main objective is to draw up a diagnosis of BoP's population in Brazil, with regard to the consumption size.

With respect to the research characterization, according to Aaker, Kumar and Day (2001), this research can be characterized as exploratory, in accordance with its purpose, research issue, the accuracy of the hypotheses developed and method of data collection. This type of research is used when an understanding is sought on the general nature of a problem, on possible alternative hypotheses and on the relevant variables that need to be regarded.

For this sort of research, the methods are quite flexible. They are not structured and qualitative, so that the researcher begins his study without preconceptions about what will be found (Aaker, Kumar and Day, 2001). The lack of a strict structure allows that different ideas and clues on the situation be investigated.

As for sources, this study used secondary surveys of specialized publications, which provided the data on the participation of $\mathrm{BoP}$ in Brazil and their main consumption characteristics that allowed the data analysis and interpretation as well as the development of initial findings under the theoretical references light.

Initially, to carry out a diagnosis on the BoP current situation, a survey of secondary data was conducted in available and reliable databases which allowed the analysis on the current participation and the trends about the BoP relevance on the Brazilian income structure.

Then data surveys were done on secondary sources about the BoP population consumption in Brazil, in order to identify a consumption pattern and an analysis in the light of the theoretical reference.

Quantitative and qualitative data were used in research, collected based on the documents analysis, evaluation of historical and current data, records, reports, governmental documents and opinions, which are suitable for the a research of exploratory nature, as described by Scharamamm (1971), Yin (1994), Miles and Huberman (1994), Schindler and Cooper (2003).

\section{Presentation and results analysis}

According to data published by CPS / FGV (2012), in 2011, the classes A and B accounted to $12 \%$ of the Brazilian population, the class $\mathrm{C}$ accounted to $55 \%$, and the classes D and E accounted to 33\%. For 2014, it is projected that the higher strata will increase their relative share in the pyramid, encompassing $15 \%$ of the population, the middle stratum will also present growth, totaling $60 \%$, and the lower classes will constitute $25 \%$. The IBGE data (2011) shown in Table 2, which serve as reference for this study, show the evolution of salary ranges over 10 years.

\section{TABLE 2 - Families per monthly household income classes in Minimum Wage (MW) -\%}

$\begin{array}{lrrrrrrrrrr}\text { Income Ranges } & 2001 & 2002 & 2003 & 2004 & 2005 & 2006 & 2007 & 2008 & 2009 & 2011 \\ \text { Up to 1 MW } & 13,1 & 13,7 & 14,6 & 13,4 & 14,9 & 14,8 & 14,2 & 13,5 & 14,1 & 12,9 \\ \text { Between 1 and 2 MW } & 19,3 & 20,2 & 20,6 & 21,7 & 22,6 & 23,4 & 22,4 & 22,3 & 23,0 & 22,3 \\ \text { Between 2 and 3 MW } & 14,7 & 15,3 & 15,9 & 15,5 & 15,9 & 17,0 & 16,8 & 16,9 & 16,9 & 17,2 \\ \text { Between 3 and 5 MW } & 18,1 & 17,9 & 18,2 & 19,1 & 18,2 & 17,6 & 18,6 & 19,2 & 19,2 & 19,1 \\ \text { Between 5 and10 MW } & 16,5 & 16,0 & 14,8 & 15,2 & 14,8 & 14,3 & 14,2 & 14,5 & 13,9 & 14,0 \\ \text { Between 10 and 20 MW } & 8,1 & 7,6 & 7,1 & 6,9 & 6,2 & 5,9 & 6,1 & 6,0 & 5,5 & 5,2 \\ \text { Over 20 MW } & 4,5 & 4,3 & 3,6 & 3,3 & 3,0 & 2,7 & 2,5 & 2,5 & 2,2 & 2,1 \\ \text { No Income } & 3,8 & 3,2 & 3,3 & 2,9 & 2,8 & 2,5 & 2,7 & 2,2 & 2,4 & 2,2 \\ \text { No Statement } & 2,1 & 1,9 & 2,0 & 2,2 & 1,6 & 2,0 & 2,5 & 2,8 & 3,0 & 4,9\end{array}$

Source: IBGE, National Sample Survey of Households 2001/2011

These data reveal that the Brazilian BoP, i.e. the population with average monthly household income below $10 \mathrm{MW}$ represents the vast majority of the population. This portion of the population accounted for $81.7 \%$ of the total population in 2001 and $85.6 \%$ of the total in 2011. Graph 1 shows the evolution of the number of BoP families in the last 10 years.

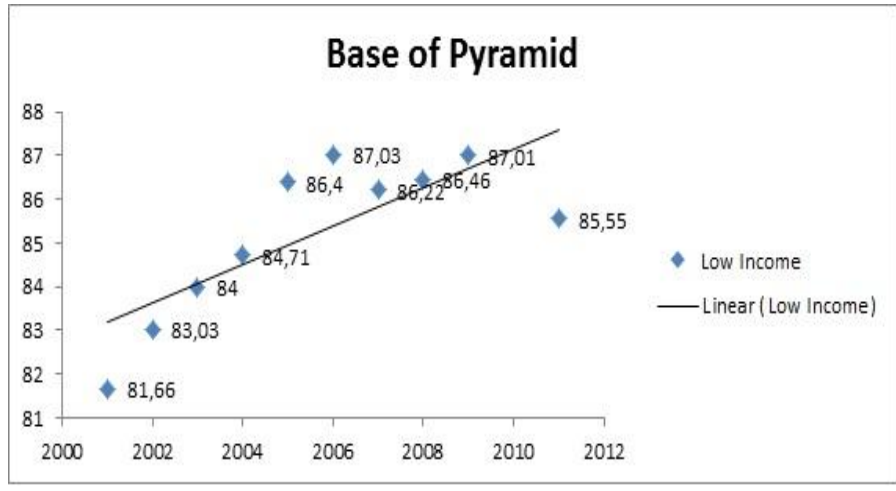

GRAPH 1 - Evolution of BoP from 2001 to 2011

Source: Prepared by the authors based on data from IBGE (2011) 
In the context of the base of the pyramid it stands out the class $\mathrm{C}$, which has always been a representative social economic class in the Brazilian social pyramid, consisting of a portion of people whose average income, according to the Brazilian Association of Research Companies (Criterion Brazil) is around $\mathrm{R} \$ 1.700,00$ (average monthly household income). In 2005 it accounted for $35 \%$ of the population, while classes $\mathrm{D} / \mathrm{E}$ were the majority, totaling $51 \%$ (Figure 1).

\section{FIGURE 1 - Economic Social Classes Evolution}

Source: Cetelem - Ipsos- 2012
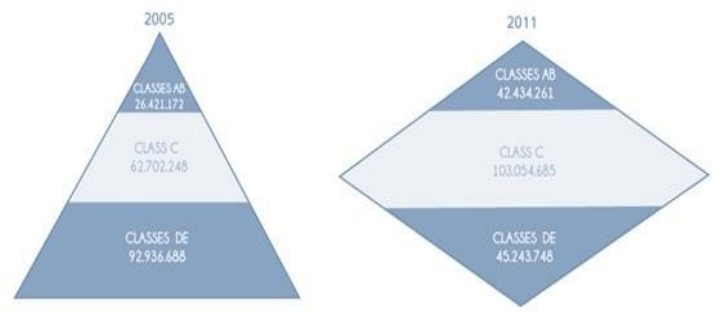

Between 2005 and 2011, approximately 40 million people turned to be part of the class $\mathrm{C}$, according to CETELEM (2012) research and as shown in Figure 1. Thus, the C class now comprises $54 \%$ of the population in 2011, compared to $24 \%$ of the classes D/E. Entry of another 30 million Brazilians is estimated in the class $\mathrm{C}$ until 2014. Thus, analyzing the social classes' evolution throughout the years, it may be noted that the class $C$ has achieved a greater room in the Brazilian population in an accelerated form.

In addition to this significant increase in the number of people belonging to the base of the pyramid, their income has also seen significant growth, being around $8 \%$ over the previous year (Class C), as shown in Graph 2. Still analyzing this graph, it can be noticed that the increase in total average household income in the country was mainly driven by the class $\mathrm{C}$ income growth.

\section{GRAPH 2 - Average household income for each consumption segment}

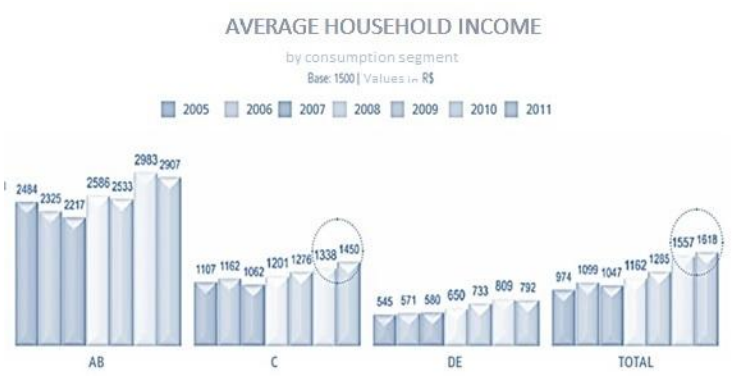

Source: Cetelem - Ipsos- 2012

\section{a. Consumption profile of the $\mathrm{BoP}$ in Brazil}

According to Wright and Spers (2011), compared with the other classes, the base of the pyramid consumers feature a consumption pattern focused on their basic needs satisfaction, the housing and food capturing most of this population income, followed by energy and transport. The data in Table 3 below support this statement, showing the size of the popular market of housing, food, transportation, clothing and health care, which represent the main expenditures of the base of the pyramid people. These data are also aligned with the concepts presented by Cobra (2009) on the relevance of key products and services in the consumption of lowincome consumers.

TABLE 3 - Overview of the percentage of expense and size of markets of the key sectors in the Brazilian family spending at the base of the pyramid

\begin{tabular}{|c|c|c|}
\hline & $\begin{array}{c}\text { Principal } \\
\text { applications of the } \\
\text { budget }\end{array}$ & $\begin{array}{l}\text { Market size in } \\
\text { the main sectors } \\
\text { (in billions) }\end{array}$ \\
\hline $\begin{array}{c}\text { Range } 1 \text { - up to } \\
2 \text { minimum } \\
\text { wages }\end{array}$ & $\begin{array}{c}\text { Housing }-37,2 \% \\
\text { Food - 32,7\% } \\
\text { Transportation - } \\
\text { 8,2\% } \\
\text { Clothes - 5,3\% } \\
\text { Medical Care - 4,1\% }\end{array}$ & $\begin{array}{c}\mathrm{R} \$ 46,2 \\
\mathrm{R} \$ 40,7 \\
\mathrm{R} \$ 10,1 \\
\mathrm{R} \$ 6,6 \\
\mathrm{R} \$ 5,1\end{array}$ \\
\hline $\begin{array}{l}\text { Range } 2 \text { - more } \\
\text { than } 2 \text { up to } 3 \\
\text { minimum wages }\end{array}$ & $\begin{array}{c}\text { Housing }-36,8 \% \\
\text { Food }-29,8 \% \\
\text { Transportation - 8,6\% } \\
\text { Clothes }-5,7 \% \\
\text { Medical Care }-4,7 \%\end{array}$ & $\begin{array}{c}\mathrm{R} \$ 39 \\
\mathrm{R} \$ 31,5 \\
\mathrm{R} \$ 9,1 \\
\mathrm{R} \$ 6,0 \\
\mathrm{R} \$ 4,9\end{array}$ \\
\hline $\begin{array}{l}\text { Range } 3 \text { - more } \\
\text { than } 3 \text { up to } 5 \\
\text { minimum wages }\end{array}$ & $\begin{array}{c}\text { Housing }-35,9 \% \\
\text { Food - 25,4\% } \\
\text { Transportation - } \\
\text { 10,9\% } \\
\text { Clothes - 5,8\% } \\
\text { Medical Care }-5,0 \%\end{array}$ & $\begin{array}{c}\mathrm{R} \$ 60,9 \\
\mathrm{R} \$ 43,2 \\
\mathrm{R} \$ 18,5 \\
\mathrm{R} \$ 9,8 \\
\mathrm{R} \$ 8,4\end{array}$ \\
\hline $\begin{array}{l}\text { Range } 4 \text { - more } \\
\text { than } 5 \text { up to } 10 \\
\text { minimum wages }\end{array}$ & $\begin{array}{c}\text { Housing }-32,7 \% \\
\text { Food }-21 \% \\
\text { Transportation - } \\
\text { 13,4\% } \\
\text { Clothes }-5,7 \% \\
\text { Medical Care }-5,2 \%\end{array}$ & $\begin{array}{c}\mathrm{R} \$ 81,1 \\
\mathrm{R} \$ 52 \\
\mathrm{R} \$ 33,2 \\
\mathrm{R} \$ 14 \\
\mathrm{R} \$ 13\end{array}$ \\
\hline
\end{tabular}

Source: Prepared by the authors based on data from IBGE (Household Budget Survey 2008-2009)

Other significant expenditures for the BoP population are health care (6\%), especially spending on medicines (4\% of income), and taxes and labor contributions, representing $4 \%$ of the expenditure.

It is noteworthy that the BoP population spends some money on tobacco (1\%), with hygiene and personal care (perfumes and personal products), and also with personal expenses, such as hairdressers (1\%). 
Relatively few resources are spent by BoP population on education (2\%), recreation and culture (1\%). These expenditures are proportionally higher for high-income population, accounting for $3 \%$ and $2 \%$ of income, respectively.

The presented data confirm the results of the survey conducted by BCG (2002), on the profile of low-income consumers. According to this study, it is hard to define a unique standard or consumption profile for the popular class, but a common feature to all profiles is that the popular class consumer does not save, or invests, he consumes.

The data in Table 4 show that the population of the base of the pyramid, on average, spends $90 \%$ of their income on consumption expenditures, reaching $94 \%$ for families with incomes up to 2 minimum wages. The classes A and B population, in contrast, spend $66 \%$ of income on consumption spending, reaching $40 \%$ in families earning more than 25 minimum wages. These data show that much of the income of the base of the pyramid is intended for consumption, especially of staple goods such as food, housing, transportation and health care. However, part of the income is also intended for goods and services that meet their personal needs of well-being, leisure and recreation, as shown in the study of BCG (2002).

TABLE 4 - Household expenditure subdivided into income classes ( $\%$ of income)

\begin{tabular}{|c|c|c|c|c|c|c|c|c|c|}
\hline \multicolumn{10}{|c|}{$\begin{array}{l}\text { Average monthly household spending (distribution) - subdivided into total } \\
\text { income classes and monthly household equity variation, according to the } \\
\text { expenses types }\end{array}$} \\
\hline \multicolumn{10}{|c|}{ Brazil } \\
\hline \multicolumn{10}{|c|}{$\begin{array}{c}\text { Variable }=\text { Cash and non-monetary average monthly household expenses } n \\
\text { (Reais }-R \$)- \text { Minimum Wage }=R \$ 415,00\end{array}$} \\
\hline \multicolumn{10}{|c|}{ Year $=2008$} \\
\hline & \multicolumn{5}{|c|}{$\begin{array}{l}\text { BASE OF THE PYRAMID } \\
\text { (CLASS C / D / E) }\end{array}$} & \multicolumn{4}{|c|}{$\begin{array}{l}\text { HIGH INCOME } \\
\text { (CLASS A / B) }\end{array}$} \\
\hline $\begin{array}{c}\text { Types } \\
\text { of } \\
\text { expens } \\
\text { es }\end{array}$ & $\begin{array}{c}\text { Up } \\
\text { to } \\
83 \\
0 \\
\text { Re } \\
\text { ais } \\
\text { Up } \\
\text { to } \\
2 \\
\text { M } \\
\text { W }\end{array}$ & $\begin{array}{c}\text { Mor } \\
\text { e } \\
\text { tha } \\
n \\
830 \\
\text { up } \\
\text { to } \\
1,2 \\
45 \\
\text { Rea } \\
\text { is - } \\
\text { Mor } \\
e \\
\text { tha } \\
\text { n } 2 \\
\text { up } \\
\text { to } 3 \\
\text { MW }\end{array}$ & $\begin{array}{c}\text { Mor } \\
\text { e } \\
\text { tha } \\
n \\
1.2 \\
45 \\
\text { up } \\
\text { to } \\
249 \\
0 \\
\text { R\$- } \\
\text { Mor } \\
\text { e } \\
\text { tha } \\
\text { n } 3 \\
\text { up } \\
\text { to } 6 \\
\text { MW }\end{array}$ & $\begin{array}{c}\text { Mor } \\
\text { e } \\
\text { tha } \\
\text { n } \\
2.4 \\
90 \\
\text { up } \\
\text { to } \\
4.1 \\
50- \\
\text { Mor } \\
e \\
\text { tha } \\
\text { n } 6 \\
\text { up } \\
\text { to } \\
10 \\
\text { MW }\end{array}$ & $\begin{array}{l}\text { B } \\
\mathbf{0} \\
\mathbf{P}\end{array}$ & $\begin{array}{c}\text { Mor } \\
\text { e } \\
\text { tha } \\
n \\
4.1 \\
50 \\
\text { up } \\
\text { to } \\
6.2 \\
25- \\
\text { mor } \\
\text { e } \\
\text { tha } \\
\text { n10 } \\
\text { up } \\
\text { to } \\
14 \\
\text { MW }\end{array}$ & $\begin{array}{c}\text { Mor } \\
\text { e } \\
\text { tha } \\
n \\
6.2 \\
25 \\
\text { up } \\
\text { to } \\
10 . \\
375 \\
- \\
\text { Mor } \\
e \\
\text { tha } \\
n \\
15 \\
\text { up } \\
\text { to } \\
25 \\
\text { Mw }\end{array}$ & $\begin{array}{c}\text { Mor } \\
\text { e } \\
\text { than } \\
10.3 \\
75- \\
\text { Mor } \\
\text { e } \\
\text { than } \\
25 \\
\text { MW }\end{array}$ & $\begin{array}{c}\text { Hig } \\
\text { h } \\
\text { Inc } \\
\text { om } \\
\text { e }\end{array}$ \\
\hline $\begin{array}{l}\text { Total } \\
\text { Expens } \\
\text { es }\end{array}$ & $\begin{array}{c}74 \\
4,9 \\
8\end{array}$ & $\begin{array}{l}1.12 \\
4,99\end{array}$ & $\begin{array}{l}1.81 \\
0,69\end{array}$ & $\begin{array}{l}3.13 \\
3,00\end{array}$ & & $\begin{array}{l}4.77 \\
8,06\end{array}$ & $\begin{array}{l}7.19 \\
6,08\end{array}$ & $\begin{array}{c}14.0 \\
98,4 \\
0\end{array}$ & \\
\hline $\begin{array}{l}\text { Consu } \\
\text { mption } \\
\text { Expens } \\
\text { es }\end{array}$ & $\begin{array}{l}94 \\
\%\end{array}$ & $\begin{array}{l}92 \\
\%\end{array}$ & $\begin{array}{l}89 \\
\%\end{array}$ & $\begin{array}{l}84 \\
\%\end{array}$ & $\begin{array}{c}9 \\
0 \\
\%\end{array}$ & $\begin{array}{l}79 \\
\%\end{array}$ & $\begin{array}{l}78 \\
\%\end{array}$ & $40 \%$ & $\begin{array}{l}66 \\
\%\end{array}$ \\
\hline
\end{tabular}

\begin{tabular}{|c|c|c|c|c|c|c|c|c|c|}
\hline Food & $\begin{array}{l}28 \\
\%\end{array}$ & $\begin{array}{l}25 \\
\%\end{array}$ & $\begin{array}{l}21 \\
\%\end{array}$ & $\begin{array}{l}17 \\
\%\end{array}$ & $\begin{array}{c}2 \\
3 \\
\%\end{array}$ & $\begin{array}{l}14 \\
\%\end{array}$ & $\begin{array}{l}12 \\
\%\end{array}$ & $6 \%$ & $\begin{array}{l}10 \\
\%\end{array}$ \\
\hline $\begin{array}{l}\text { Housin } \\
\quad \mathbf{g}\end{array}$ & $\begin{array}{l}37 \\
\%\end{array}$ & $\begin{array}{l}37 \\
\%\end{array}$ & $\begin{array}{l}33 \\
\%\end{array}$ & $\begin{array}{l}30 \\
\%\end{array}$ & $\begin{array}{l}3 \\
4 \\
\%\end{array}$ & $\begin{array}{l}28 \\
\%\end{array}$ & $\begin{array}{l}25 \\
\%\end{array}$ & $13 \%$ & $\begin{array}{l}22 \\
\%\end{array}$ \\
\hline Clothes & $5 \%$ & $5 \%$ & $5 \%$ & $5 \%$ & $\begin{array}{c}5 \\
\%\end{array}$ & $4 \%$ & $4 \%$ & $2 \%$ & $3 \%$ \\
\hline $\begin{array}{c}\text { Transp } \\
\text { ortatio } \\
n\end{array}$ & $\begin{array}{l}10 \\
\% \\
\end{array}$ & $\begin{array}{l}11 \\
\% \\
\end{array}$ & $\begin{array}{l}14 \\
\% \\
\end{array}$ & $\begin{array}{l}17 \\
\%\end{array}$ & $\begin{array}{c}1 \\
3 \\
\% \\
\end{array}$ & $\begin{array}{l}17 \\
\% \\
\end{array}$ & $\begin{array}{l}20 \\
\% \\
\end{array}$ & $10 \%$ & $\begin{array}{l}16 \\
\%\end{array}$ \\
\hline $\begin{array}{c}\text { Hygien } \\
\text { e and } \\
\text { Person } \\
\text { al care }\end{array}$ & $3 \%$ & $3 \%$ & $3 \%$ & $2 \%$ & $\begin{array}{l}3 \\
\%\end{array}$ & $2 \%$ & $2 \%$ & $1 \%$ & $1 \%$ \\
\hline $\begin{array}{l}\text { Medical } \\
\text { care }\end{array}$ & $5 \%$ & $6 \%$ & $6 \%$ & $6 \%$ & $\begin{array}{l}6 \\
\%\end{array}$ & $6 \%$ & $6 \%$ & $3 \%$ & $5 \%$ \\
\hline $\begin{array}{c}\text { Educati } \\
\text { on }\end{array}$ & $1 \%$ & $1 \%$ & $2 \%$ & $2 \%$ & $\begin{array}{l}2 \\
\% \\
\end{array}$ & $3 \%$ & $4 \%$ & $2 \%$ & $3 \%$ \\
\hline $\begin{array}{l}\text { Recrea } \\
\text { tion } \\
\text { and } \\
\text { Culture }\end{array}$ & $1 \%$ & $1 \%$ & $2 \%$ & $2 \%$ & $\begin{array}{l}1 \\
\%\end{array}$ & $2 \%$ & $2 \%$ & $1 \%$ & $2 \%$ \\
\hline $\begin{array}{c}\text { Smokin } \\
\mathbf{g}\end{array}$ & $1 \%$ & $1 \%$ & $0 \%$ & $0 \%$ & $\begin{array}{l}1 \\
\% \\
\end{array}$ & $0 \%$ & $0 \%$ & $0 \%$ & $0 \%$ \\
\hline 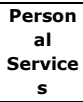 & $1 \%$ & $1 \%$ & $1 \%$ & $1 \%$ & $\begin{array}{l}1 \\
\%\end{array}$ & $1 \%$ & $1 \%$ & $1 \%$ & $1 \%$ \\
\hline $\begin{array}{l}\text { Miscell } \\
\text { aneous }\end{array}$ & $2 \%$ & $2 \%$ & $2 \%$ & $2 \%$ & $\begin{array}{l}2 \\
\%\end{array}$ & $3 \%$ & $3 \%$ & $1 \%$ & $2 \%$ \\
\hline 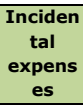 & $3 \%$ & $4 \%$ & $9 \%$ & $9 \%$ & $\begin{array}{l}6 \\
\%\end{array}$ & $\begin{array}{l}11 \\
\%\end{array}$ & $\begin{array}{l}14 \\
\%\end{array}$ & $7 \%$ & $\begin{array}{l}11 \\
\%\end{array}$ \\
\hline Taxes & $1 \%$ & $1 \%$ & $3 \%$ & $3 \%$ & $\begin{array}{l}2 \\
\% \\
\end{array}$ & $4 \%$ & $6 \%$ & $3 \%$ & $5 \%$ \\
\hline $\begin{array}{l}\text { Labor } \\
\text { contrib } \\
\text { utions }\end{array}$ & $1 \%$ & $2 \%$ & $3 \%$ & $3 \%$ & $\begin{array}{c}2 \\
\% \\
\end{array}$ & $3 \%$ & $4 \%$ & $2 \%$ & $3 \%$ \\
\hline $\begin{array}{c}\text { Bankin } \\
\mathbf{g} \\
\text { Service } \\
\mathbf{s}\end{array}$ & $0 \%$ & $0 \%$ & $0 \%$ & $0 \%$ & $\begin{array}{l}0 \\
\%\end{array}$ & $0 \%$ & $1 \%$ & $0 \%$ & $0 \%$ \\
\hline $\begin{array}{c}\text { Pensio } \\
\text { ns, } \\
\text { allowa } \\
\text { nces } \\
\text { and } \\
\text { donatio } \\
\text { ns } \\
\end{array}$ & $1 \%$ & $1 \%$ & $1 \%$ & $1 \%$ & $\begin{array}{l}1 \\
\%\end{array}$ & $1 \%$ & $1 \%$ & $1 \%$ & $1 \%$ \\
\hline $\begin{array}{c}\text { Private } \\
\text { Social } \\
\text { Securit } \\
y\end{array}$ & $0 \%$ & $0 \%$ & $0 \%$ & $0 \%$ & $\begin{array}{l}0 \\
\%\end{array}$ & $0 \%$ & $0 \%$ & $0 \%$ & $0 \%$ \\
\hline $\begin{array}{c}\text { Other } \\
\text { Expens } \\
\text { es }\end{array}$ & $0 \%$ & $0 \%$ & $1 \%$ & $1 \%$ & $\begin{array}{l}0 \\
\%\end{array}$ & $1 \%$ & $2 \%$ & $1 \%$ & $1 \%$ \\
\hline $\begin{array}{c}\text { Assets } \\
\text { increas } \\
\text { e }\end{array}$ & $2 \%$ & $2 \%$ & $3 \%$ & $5 \%$ & $\begin{array}{c}3 \\
\%\end{array}$ & $8 \%$ & $6 \%$ & $3 \%$ & $5 \%$ \\
\hline $\begin{array}{c}\text { Propert } \\
\text { y } \\
\text { (acquis } \\
\text { ition) }\end{array}$ & $1 \%$ & $1 \%$ & $1 \%$ & $3 \%$ & $\begin{array}{c}1 \\
\%\end{array}$ & $6 \%$ & $4 \%$ & $2 \%$ & $4 \%$ \\
\hline $\begin{array}{l}\text { Propert } \\
y \\
\text { (renov } \\
\text { ation) }\end{array}$ & $1 \%$ & $1 \%$ & $2 \%$ & $2 \%$ & $\begin{array}{l}2 \\
\%\end{array}$ & $2 \%$ & $2 \%$ & $1 \%$ & $2 \%$ \\
\hline $\begin{array}{l}\text { Other } \\
\text { Invest } \\
\text { ments }\end{array}$ & $0 \%$ & $0 \%$ & $0 \%$ & $0 \%$ & $\begin{array}{l}0 \\
\%\end{array}$ & $0 \%$ & $0 \%$ & $0 \%$ & $0 \%$ \\
\hline $\begin{array}{l}\text { Decrea } \\
\text { se of } \\
\text { liabiliti } \\
\text { es }\end{array}$ & $1 \%$ & $1 \%$ & $2 \%$ & $2 \%$ & $\begin{array}{c}2 \\
\%\end{array}$ & $2 \%$ & $2 \%$ & $1 \%$ & $2 \%$ \\
\hline $\begin{array}{c}\text { Loan } \\
\text { and } \\
\text { payme } \\
\text { nt } \\
\text { booklet }\end{array}$ & $1 \%$ & $1 \%$ & $1 \%$ & $1 \%$ & $\begin{array}{l}1 \\
\%\end{array}$ & $2 \%$ & $2 \%$ & $1 \%$ & $1 \%$ \\
\hline $\begin{array}{c}\text { Propert } \\
\text { y } \\
\text { Install } \\
\text { ment }\end{array}$ & $0 \%$ & $1 \%$ & $1 \%$ & $1 \%$ & $\begin{array}{l}0 \\
\%\end{array}$ & $1 \%$ & $1 \%$ & $0 \%$ & $1 \%$ \\
\hline
\end{tabular}

Part of the expenses made by the base of the pyramid consumers should also offer them a sense of belonging to some social group, as presented in the theoretical 
reference. According to Oliveira (2006), for the BoP population, consumption is a way to feel part of society. Consuming is good for such consumer's self-esteem. Spending on appliances, clothing and shoes, vehicle acquisition, personal care products, recreation and culture should represent this inclusion role, in addition to meeting the essential basic needs.

\section{Conclusion (Final thoughts)}

The main objective of this study is to outline a diagnosis of the BoP's population in Brazil, with regard to the consumption size. To achieve this goal, a theoretical survey was made in the international literature, and especially in Brazilian literature, identifying the base of the pyramid main characteristics. After the theoretical survey, a research was made based on secondary data about the Brazilian BoP population participation and a mapping of the consumption profile, identifying the main categories of the goods consumed.

The definition adopted in this study for the BoP population (or also known as low-income or popular) is the one that uses the classification by average monthly household income, based on the data from the National Household Sample Survey (PNAD-IBGE, 2010). Based on this study, the popular class is composed of families with income up to 10 minimum monthly wages.

The data show that there was a population increase of the Brazilian BoP in the last 10 years, from $82 \%$ of the population in 2002 to $86 \%$ in 2012. It is noteworthy that this increase was mainly due to enlargement of the class $\mathrm{C}$, having in view a narrowing of the classes D/E mostly. Such analyses show the class $C$ strengthening and it has now a stronger appearance and more importance in consumption context.

In addition to this significant increase in the number of people belonging to $\mathrm{BoP}$, their income has also seen significant growth, around 8\% in 2011 compared to 2010, for the class C, according to data analyzed. The data show that the increase in total average household income in the country was mainly driven by the class $\mathrm{C}$ income growth.

These analyses confirm the statements made in the theory about the base of the pyramid relevance and its consumption potential according to statement of foreign authors Prahalad and Hammond, 2002; Prahalad and Hart, 2002; Prahalad, 2004 and the Brazilian authors Giovinazzo, 2003; Spers, 2007.

By analyzing the data on consumption, it may be concluded that in general, the average expenditures of the
BoP population are concentrated in essential expenditures, especially housing, food, transportation and clothing, which constitute $70 \%$ of the BoP population expenditures and only $48 \%$ of the expenditures of highincome population. These expenditures include rents, home maintenance, electricity, gas, water and sewage, clothing and shoes, urban transportation and vehicle acquisition.

In addition to expenditures essential goods, the BoP population also spends money on health care, smoking, hygiene and personal care (perfumes and personal products) and personal expenses, such as hairdressing, recreation and culture. It is remarkable that few resources are spent on education by the BoP population. The base of the pyramid population, on average, spends $90 \%$ of their income on consumption expenditures, reaching $94 \%$ for families with incomes up to 2 minimum wages.

These results are aligned with the theory that the BoP population hardly saves or invests, it consumes, spending much of their income on consumer goods, whether they are essential or not. It is worth noting that this behavior is closely related to the income restriction, but also to the concept of belonging to a social group, and to the base of the pyramid population. Consumption is a way of social inclusion, makes the consumer feel as an integral part of society. Consuming is good for such consumer selfesteem.

These findings are relevant to decision makers within organizations, considering the relevance of the BoP population as a consumer market. It is also valuable to know the main categories of products that are part of the consumption basket of the BoP population BP, and its preferences. These conclusions should also be taken into account by public policy managers, especially on the issue of education for the BoP, when considering the small amount of money this population assigns to its own education. It is also important to understand that consumption represents the economic and social inclusion of this population.

The study carries some theoretical and methodological limitations. Main limitation is the fact that, the study was based only on secondary data. In order to make the research richer and more complete, it would be interesting to consult the BoP population through primary research with quantitative approach (surveys) or qualitative, such as focus groups. It would also be ideal to consult a panel of experts in different areas, so that, with their experience, they can complement the diagnosis obtained in this study, based on secondary data. It would be interesting to analyze the market (Brazil) and BoP from different perspectives, considering different sectors, 
such as the tourism demand perspective, and other important sectors.

The research carried out here allowed a consolidated analysis on the participation of the BoP population in Brazil, as well as the income evolution of this population. The analyses lead to the confirmation of BoP as a consumer segment of the population. The analyzed data also reveal the consumption profile of the $\mathrm{BoP}$, reinforcing a general perception that the essential goods are relevant for this population, but also allowing for a deeper analysis on the perception of this population segment with regard to price, quality and consumption of goods that bring a higher personal satisfaction and sense of belonging to a social group and social inclusion. The results are important for the strategic planning of companies from different sectors, such as housing, food, transportation, clothing, health care, education and recreation, including tourism.

\section{REFERENCES}

Aaker, D. A., et al. (2011) Pesquisa de Marketing. São Paulo: Editora Atlas.

Aaker, D.A., Kumar, V. and Day, G.S. (2001), Marketing Research (7th edition), John Wiley and Son Inc, New York.

BCG (2002). Mercados pouco explorados: descobrindo a classe C. Boston Consulting Group: São Paulo.

Cetelem. (2012) Pesquisa Anual: O Observador Brasil 2012. São Paulo. Available

at: http://www.cetelem.com.br/portal/Sobr e_Cetelem/Observador.shtml.

Cobra, Marcos. (2009) Administração de marketing no Brasil. São Paulo: Elsevier. $3^{\mathrm{a}}$ edição.
Cooper, D. R. Schindler, P. S. (2003) Métodos de Pesquisa em Administração. Porto Alegre: Bookman.

Cps/Fgv. (2012) De volta ao país do futuro: projeções, crise européia e a nova classe média. Fundação Getúlio Vargas - Centro de Políticas Sociais: Rio de Janeiro. Disponível em <http://www.fgv.br/cps/ncm2014/>.

Acesso em: 30/04/2012.

Data Popular. (2006) O mercado da base da pirâmide no Brasil. Disponível em: $<$ http://www.datapopular.com.br/>. Acesso em: 19/05/2012.

Giovinazzo, R. A. (2003) Um estudo sobre o desempenho e a estratégia das empresas que atuam no mercado de bens populares no Brasil. Dissertação (Mestrado em Administração de Empresas). São Paulo: Faculdade de Economia, Administração e Contabilidade da Universidade de São Paulo.

Green, P. E. Carmone, F. J. (1988) Multidimensional scaling and related techniques in marketing analysis. Boston: Allyn. 
Hammond, A.L. Kramer, W.J. Katz, R.S. Tran and C. Walker, J.T. (2007) The next four billion: market size and business strategy at the base of the pyramid.

World Resources Institute and International Finance Corporation. Washington, DC.

Hammond, A.L. Prahalad, C.K. (2004) Selling to the poor, For Pol.

Hart, S.L. London, T. (2005) Developing native capability: what multinational corporations can learn from the base of the pyramid. Stanford Social Innovation Review.

Hart, S.L. (2005) Capitalism at the crossroads: the unlimited business opportunities in serving the world's most difficult problems. NJ: Wharton School Publishing.

IBGE. Censo 2010. Available at: <http://www.censo2010.ibge.gov.br/pri meiros_dados_divulgados/index.php?u $f=00 />$.

London, T. Hart, S.L. (2004) Reinventing strategies for emerging markets: beyond the transnational model, Journal of International Business Studies.
London, T. Anupindi, R. Sheth, S. (2009) Creating mutual value: Lessons learned from serving base of the pyramid producers. Journal of Business Research.

London, T. Janiga, K. Valente, M. (2007) The base of the pyramid perspective and the social enterprise methodology: understanding the facilitating role for development agencies. MI: William Davidson Institute.

Malhorta, N. (1996) Marketing research: an applied orientation. Upper Sadlle River: Prentice Hall.

Miles, B. M. Huberman, A. M. (1994) Qualitative data analysis: an expanded sourcebook. California: Sage.

Oliveira, Mariana. (2006). A base da pirâmide torna-se o topo das vendas. Mundo do Marketing. Available at: http://mundodomarketing.com.br/.. 
Prado, Karen Perrotta Lopes de Almeida. (2008) A preferência da marca no processo de decisão de compra: um estudo exploratório no segmento de baixa renda. São Paulo. Tese de Doutorado - Departamento de Administração da Faculdade de Economia, Administração e Contabilidade da Universidade de São Paulo.

Prahalad, C.K. (2005) Aid is not the answer. Wall Street Journal.

Prahalad, C.K. (2004) The fortune at the bottom of the pyramid: eradicating poverty through profits, Wharton School Publishing, Upper Saddle River, NJ.

Prahalad, C.K. and Hammond, A. (2002) Serving the world's poor, profitably, Harvard Business Review.

Prahalad, C.K. Hart, S.L. (2002) The fortune at the bottom of the pyramid. Strategic Business.

Scharamamm, V. (1971) Notes: case studies of instructorial media projects. Working Paper for Academy Educational Development,. Washington.
Spers, R. G. (2007) Proposição de um modelo de internacionalização para atuação de empresas brasileiras nos mercados populares internacionais. Tese (Doutorado em Administração de Empresas). São Paulo: Faculdade de Economia, Administração e Contabilidade da Universidade de São Paulo.

Spers, R. G. Wright, J. T. C. (2006) Mercado de bens populares no Brasil: desempenho e estratégia das empresas, RPA Brasil, v. 3, p. 5-18, Maringá.

Vaz, Danielle. (2006) Estratégias de marketing para o consumidor na base da pirâmide. São Paulo. Disponível em: http://www.ead.fea.usp.br/tcc/trabalhos . Acessado em 19/05/2012.

Wright, James Terence Coulter; Spers, Renata Giovinazzo. (2011) Mercado popular no Brasil: abordagens para geração de negócios e casos de sucesso. São Paulo: Blucher, 2011.

Yin, R. K. (1994) Case study research: design and methods. California Sage. 